\title{
APLIKASI TEORI CONDITIONING-REINFORCEMENT- SCAFFOLDING BERBANTUAN BAHAN AJAR MASTERY LEARNING PADA MATA KULIAH TEORI GRUP UNTUK MENINGKATKAN KEMAMPUAN PEMBUKTIAN MATEMATIS MAHASISWA
}

\author{
Mokhammad Ridwan Yudhanegara ${ }^{1)}$, Budi Hari Priyanto ${ }^{2)}$ \\ Karunia Eka Lestari ${ }^{3)}$ \\ Pendidikan Matematika Fakultas Keguruan dan Ilmu Pendidikan \\ Universitas Singaperbangsa Karawang, Jalan H.S Ronggowaluyo Telukjambe Karawang \\ 1) mridwan.yudhanegara@staff.unsika.ac.id ${ }^{2)}$ budihp.mtkfkip@gmail.com \\ ${ }^{3)}$ karunia@staff.unsika.ac.id
}

\begin{abstract}
Group Theory course is contained the definitions, proof of theorem, and lemma so that in order to understand it, the students must have a good mathematical proofing ability. Furthermore, this article examines the comparative improvement of students' mathematical proofing abilities in the course of Group Theory. Comparisons were performed on three groups chosen purposively by subject matching techniques. The result of the research shows that at $95 \%$ level of confidence there is a difference in the improvement of students' mathematical proofing ability between those who get learning through the application of CRS theory with mastery learning materials, with students who get learning through CRS theory application and students who get learning through the application of constructivism theory.

Keyword: Mathematical Proofing Ability, Conditioning, Reinforcement, Scaffolding, Mastery Learning
\end{abstract}

Abstrak
Mata kuliah Teori Grup sarat dengan definisi, pembuktian teorema, dan
lemma sehingga agar dapat memahaminya, mahasiswa harus memiliki
kemampuan pembuktian matematis yang baik. Secara lebih lanjut, artikel ini
mengkaji tentang perbandingan peningkatan kemampuan pembuktian matematis
mahasiswa pada mata kuliah Teori Grup. Perbandingan dilakukan pada tiga
kelompok yang dipilih secara purposive dengan teknik pencocokan subjek. Hasil
penelitian menunjukkan bahwa pada taraf kepercayaan 95\%, terdapat perbedaan
peningkatan kemampuan pembuktian matematis mahasiswa antara yang
mendapatkan pembelajaran melalui aplikasi teori CRS berbantuan bahan ajar
mastery learning, dengan mahasiswa yang mendapatkan pembelajaran melalui
aplikasi teori CRS saja dan mahasiswa yang mendapatkan pembelajaran melalui
aplikasi teori konstruktivisme.
Kata Kunci: Kemampuan Pembuktian Matematis, Conditioning, Reinforcement,
Scaffolding, Mastery Learning




\section{PENDAHULUAN}

Kemampuan

pembuktian matematis merupakan kemampuan dasar yang memiliki peran penting pada mata kuliah Teori Grup. Hal ini dikarenakan mata kuliah Teori Grup sarat dengan definisi, pembuktian teorema, dan lemma sehingga agar dapat memahaminya, mahasiswa harus memiliki kemampuan dalam membuktikan teorema dan lemma yang dipelajari, serta membuktikan beberapa permasalahan yang terkait dengan penerapan definisi, teorema, dan lemma (Findel, 2001).

Hasil penelitian Lestari (2015) pada mahasiswa semester VII tahun ajaran 2014-2015 Program Studi Pendidikan Matematika FKIP UNSIKA menunjukkan adanya permasalahan yang dihadapi mahasiswa dalam melakukan pembuktian matematis, diantaranya: (1) permasalahan dalam membaca dan memahami pembuktian matematis; (2) menyajikan bukti kebenaran suatu pernyataan secara matematis; (3) melakukan pembuktian secara langsung, tak langsung atau dengan induksi matematika (4) dan mengembangkan argumen matematis untuk membuktikan atau menyangkal suatu pernyataan.

Permasalahan di atas menunjukkan bahwa dari sisi mahasiswa, kemampuan pembuktian matematis merupakan kemampuan yang tidak mudah untuk dipelajari. Sementara itu, dari sisi dosen, mengajarkan pembuktian matematis pun bukan perkara yang mudah. Pada umumnya dosen menerapkan teori konstruktivisme dalam menyampaikan materi pada perkuliahan Teori Grup. Proses pembelajaran melalui implementasi teori konstruktivisme pada perkuliahan Teori Grup umumnya lebih menekankan pada proses dan kebebasan dalam menggali pengetahuan serta upaya mengkonstruksi bukti matematis secara mandiri. Dengan demikian, kegiatan perkuliahan didominasi oleh mahasiswa.

Namun proses pembelajaran melalui implementasi teori kontruktivisme tidak begitu efektif ketika diterapkan pada mahasiswa Program Studi Pendidikan Matematika FKIP UNSIKA. Mengingat karateristik mahasiswa Program Studi Pendidikan Matematika FKIP UNSIKA mayoritas adalah sebagai pekerja (guru honorer, tenaga administrasi, buruh pabrik), yang mana sebagian besar aktivitas mahasiswa disibukkan oleh kegiatan lain selain belajar, sehingga waktu belajar dan kemandirian mahasiswa dalam belajar sangat terbatas.

Sehubungan dengan hal di atas, dominasi dosen dalam menyampaikan materi pada saat perkuliahan sangat diperlukan. Dosen juga perlu mengembangkan metode pembelajaran yang mempertimbangkan aspek karakteristik mahasiswa. Mengingat mahasiswa yang dihadapi memiliki waktu belajar dan kemandirian mahasiswa dalam belajar sangat terbatas, maka diperlukan pembiasaan (conditioning), penguatan (reinforcement), dan bantuan yang 
dapat menjembatani (scaffolding) mahasiswa dalam mengkonstruksi pembuktian matematis.

Conditioning diperlukan agar mahasiswa terbiasa dalam melakukan pembuktian matematis. Proses conditioning dapat dilakukan melalui serangkaian kegiatan drill and exercise yang diselenggarakan dalam bentuk kuis tertulis dan kuis lisan. Agar mahasiswa termotivasi dan bersungguh-sungguh dalam mengikuti proses conditioning, maka diperlukan reinforcement dengan penambahan dan pengurangan skor. Sementara itu, guna membantu mahasiswa dalam mengkontruksi pembuktian matematis, dosen memberikan scaffolding melalui teknik probing, yakni problem possing dan problem prompting.

Di samping pemberian scaffolding, dosen juga memberikan bantuan berupa pemberian bahan ajar mastery learning terkait materi yang disampaikan pada mata kuliah Teori Grup. Pemberian bahan ajar tersebut bertujuan agar mahasiswa dapat menguasai kompetensi-kompetensi secara utuh dan tuntas (mastery learning) sesuai dengan kecepatan belajarnya, mulai dari yang mudah untuk memahami yang sulit, dan dari yang konkret untuk memahami yang abstrak, serta melakukan pembuktian matematis secara mandiri.

Berdasarkan uraian di atas, menjadi hal yang urgen untuk melakukan penelitian mengenai aplikasi teori conditioningreinforcement-scaffolding berbantuan bahan ajar mastery learning pada mata kuliah Teori Grup untuk meningkatkan

kemampuan

pembuktian matematis mahasiswa.

Melalui penelitian tersebut, diharapkan dapat memberikan kontribusi bagi pengembangan metode pembelajaran, khususnya untuk diterapkan dalam perkuliahan Teori Grup guna meningkatkan kemampuan pembuktian matematis mahasiswa.

Tujuan dari penelitian ini adalah:

1. Menganalisis tentang perbedaan peningkatan kemampuan pembuktian matematis mahasiswa antara yang mendapatkan pembelajaran melalui aplikasi teori CRS berbantuan bahan ajar mastery learning, dengan mahasiswa yang mendapatkan pembelajaran melalui aplikasi teori CRS saja dan mahasiswa yang mendapatkan pembelajaran melalui aplikasi teori konstruktivisme.

2. Menganalisis tentang perbedaan peningkatan kemampuan pembuktian matematis mahasiswa yang mendapatkan pembelajaran melalui aplikasi teori CRS berbantuan bahan ajar mastery learning ditinjau berdasarkan pencapaian indikator kemampuan pembuktian matematis.

\section{LANDASAN TEORI}

\section{Kemampuan Pembuktian Matematis}

Kemampuan pembuktian matematis adalah kemampuan memahami pernyataan atau simbol metematika serta menyusun bukti kebenaran suatu pernyataan secara matematis berdasarkan definisi, 
prinsip, dan teorema. Hasil penelitian

Lestari dan Yudhanegara (2015) menunjukkan terdapat permasalahan yang dihadapi mahasiswa dalam melakukan pembuktian matematis, terutama dalam memahami dan melakukan pembuktian matematis. Oleh karena itu, indikator kemampuan pembuktian matematis yang diukur dalam penelitian ini yaitu: 1) membaca pembuktian matematis; 2) melakukan pembuktian matematis secara langsung, tak langsung, atau dengan induksi matematis; dan 3) mengkritik pembuktian dengan menambah, mengurangi atau menyusun kembali suatu pembuktian matematis.

\section{Implementasi Teori CRS \\ Berbatuan Bahan Ajar Mastery Learning}

Pembelajaran

melalui

implementasi teori CRS merupakan suatu skema pembelajaran yang menggabungkan keunggulan teori conditioning dari Ivan P. Pavlov, teori reinforcement dari B.F.Skinner, dan teori scaffolding dari Lev S. Vygotsky. Penggabungan teori-teori tersebut didasarkan pada hasil penelitian Lestari dan Yudhanegara (2015) mengenai faktor penyebab kesulitan mahasiswa dalam melakukan pembuktian matematis diantaranya adalah faktor kurangnya intensitas latihan, kurangnya penguatan dan intervensi yang diberikan dosen. Selanjutnya peneliti melakukan pengkajian dari beberapa teori belajar yang telah ada dan berinisiatif untuk menggabungkan keunggulan dari tiga teori tersebut.
Skema pembelajaran melalui implementasi teori CRS terdiri dari tiga fase utama, yakni: conditioning, reinforcement, dan scaffolding. Fase pertama mahasiswa dikondisikan (conditioning) agar terbiasa dalam melalukan pembuktian matematis melalui serangkaian kegiatan drill and exercise. Kegiatan tersebut dilaksanakan dalam bentuk kuis tertulis pada setiap awal perkuliahan dan kuis lisan selama perkuliahan berlangsung.

Pada fase kedua mahasiswa diberikan penguatan (reinforcement) dengan penambahan skor sebesar 85 bagi mahasiswa yang dapat menjawab pertanyaan dalam kuis lisan, dan pengurangan skor sebesar 50 bagi mahasiswa yang menjawab dengan keliru serta 60 bagi mahasiswa yang tidak dapat menjawab sama sekali. Dengan demikian, fase ini mengharuskan mahasiswa untuk dapat berusaha secara optimal dalam melakukan pembuktian matematis.

Fase ketiga merupakan fase pemberian sejumlah bantuan yang dapat menjembatani (scaffolding) mahasiswa untuk melakukan pembuktian matematis. Scaffolding diberikan melalui teknik probing, yakni probing possing dan probing prompting, baik berupa petunjuk pembuktian, memberikan contoh pembuktian atau memposting bahan ajar serta contoh latihan soal pembuktian di halaman blog, facebook, whatsapp (sosial media) sehingga memungkinkan mahasiswa untuk belajar secara mandiri kapan pun dan dimana pun. 
Di samping itu, pemberian bantuan juga dilakukan melalui pemberian bahan ajar mastery learning. Bahan ajar mastery learning merupakan seperangkat materi ajar yang disusun secara sistematis sehingga tercipta lingkungan belajar yang memungkinkan mahasiswa untuk dapat menguasai kompetensikompetensi secara utuh dan tuntas (mastery learning) sesuai dengan kecepatan belajarnya. Bahan ajar tersebut disusun dalam bentuk buku ajar dengan menyajikan materi mulai dari yang mudah untuk memahami yang sulit, dan dari yang konkret untuk memahami yang abstrak.

\section{Implementasi}

Teori

\section{Konstruktivisme}

Pembelajaran

melalui

implementasi teori konstruktivisme lebih menekankan pada proses dan kebebasan dalam menggali pengetahuan serta upaya mengkonstruksi pengalaman. Teori ini pertama kali dikembangkan oleh Jean Piaget melalui sumbangan pemikirannya yang banyak digunakan sebagai rujukan untuk memahami perkembangan kognitif individu yaitu teori tentang tahapan perkembangan individu. Dalam penelitian ini, implementasi teori konstruktivisme dijadikan sebagai kontrol terhadap perlakuan. Hal tersebut didasarkan pada pertimbangan bahwa teori konstruktivisme merupakan teori yang biasanya digunakan oleh dosen pengampu mata kuliah Teori Grup.

\section{METODOLOGI \\ Jenis Penelitian}

Penelitian ini menggunakan pendekatan kuantitatif dengan metode eksperimen. Eksperimen dilakukan dengan memberikan treatment melalui treatment berupa pemberian perlakuan pembelajaran melalui aplikasi teori CRS berbantuan bahan ajar mastery learning pada perkuliahan Teori Grup. Pemberian treatment diarahkan untuk meningkatkan kemampuan pembuktian matematis mahasiswa. Adapun desain penelitian yang digunakan adalah quasi experimental; the matching-only pretest-posttest control group design. Paradigma penelitian diilustrasikan oleh Lestari dan Yudhanegara (2015) sebagai berikut:

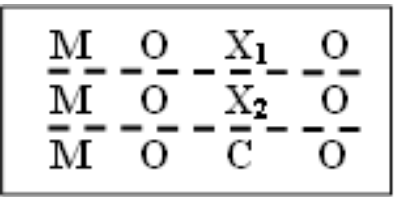

Gambar 1.

Desain Penelitian

Populasi dan Sampel Penelitian

Populasi dalam penelitian ini adalah seluruh mahasiswa semester IV ajaran
2016-2017 Program Studi Pendidikan Matematika FKIP UNSIKA yang mengontrak mata kuliah Teori Grup 
sebanyak 205 orang. Adapun sampel penelitian ini melibatkan tiga kelompok mahasiswa, dengan masingmasing kelompok sebanyak 30 orang, yang dipilih menggunakan teknik sampling purposive dengan pencocokan subyek (matched subject). Pencocokan subyek tersebut dilakukan dengan cara memasangkan individuindividu berdasarkan kriteria tertentu. Kriteria tersebut ditentukan dengan

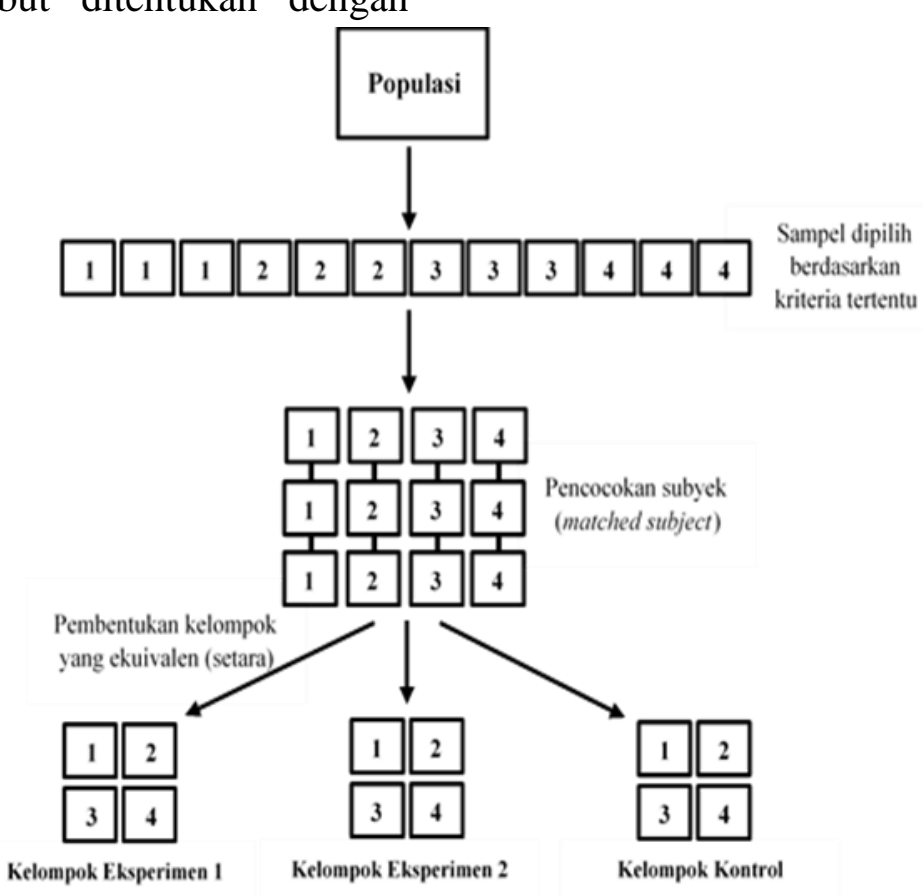

Gambar 2.

Teknik Sampling secara Purposive dengan Pencocokan Subyek

\section{Waktu dan Tempat Penelitian}

Penelitian dilakasanakan pada Semester IV Tahun Akademik 2016/2017 pada Program Studi Pendidikan Matematika Fakultas Keguruan dan Ilmu Pendidikan Universitas Singaperbangsa

Karawang.

\section{Prosedur Penelitian}

Secara umum prosedur dalam penelitian ini meliputi empat tahap yaitu Persiapan, Pelasanaan, Analisis Data, membuat mempertimbangkan kemampuan awal matematis (KAM) mahasiswa yang diperoleh berdasarkan hasil placement test (sebelum dilakukan pretes). Cara ini dilakukan sebagai upaya untuk memperoleh kelompok yang ekuivalen (setara). Lestari dan Yudhanegara (2015) mengilustrasikan cara penentuan sampel dengan pencocokan subyek sebagai berikut: 
hasil analisis data dan temuan di lapangan.

\section{Data, Instrumen dan Teknik Pengumpulan Data}

Hal yang perlu diperhatikan dalam mengumpulkan data diantaranya yaitu menentukan sumber data, jenis data, teknik pengumpulan, dan instrumen yang digunakan. Teknik pengumpulan data secara lengkap disajikan pada Tabel 1.

Tabel 1.

Teknik Pengumpulan Data

\begin{tabular}{|c|c|l|c|c|}
\hline No & $\begin{array}{c}\text { Sumber } \\
\text { Data }\end{array}$ & \multicolumn{1}{|c|}{ Jenis Data } & $\begin{array}{c}\text { Teknik } \\
\text { Pengumpulan }\end{array}$ & Instrumen \\
\hline 1. & Mahasiswa & $\begin{array}{l}\text { Kemampuan prasyarat } \\
\text { mahasiswa }\end{array}$ & Tes & $\begin{array}{c}\text { Tes } \\
\text { Diagnosis }\end{array}$ \\
\hline 2. & $\begin{array}{c}\text { Jurnal, Text } \\
\text { Book, } \\
\text { Learning } \\
\text { Materials }\end{array}$ & $\begin{array}{l}\text { Bahan ajar } \\
\text { berdasarkan konsep } \\
\text { mastery learning }\end{array}$ & Studi Literatur & Dokumentasi \\
\hline 3. & Mahasiswa & $\begin{array}{l}\text { Kemampuan awal } \\
\text { matematis (KAM) } \\
\text { mahasiswa }\end{array}$ & Tes & $\begin{array}{c}\text { Placement } \\
\text { test }\end{array}$ \\
\hline 5. & Mahasiswa & $\begin{array}{l}\text { Kemampuan awal } \\
\text { pembuktian matematis } \\
\text { mahasiswa }\end{array}$ & Tes & Pretest \\
\hline Mahasiswa & $\begin{array}{l}\text { Kemampuan akhir } \\
\text { pembuktian matematis } \\
\text { mahasiswa }\end{array}$ & Tes & Posttest \\
\hline
\end{tabular}

\section{Analisis Data}

Teknik analisis data melalui studi kuantitatif dilakukan untuk menjawab rumusan masalah yang menanyakan mengenai peningkatan kemampuan pembuktian matematis mahasiswa yang mendapatkan bahan ajar berdasarkan konsep mastery learning serta pembelajaran melalui implementasi teori CRS pada mata kuliah Teori grup. Guna menjawab pertanyaan tersebut, peneliti memiliki tiga dugaan (hipotesis) yang telah dirumuskan pada bagian hipotesis penelitian. Berikut ini tahapan pengujiannya:

a) Menentukan nilai $\mathrm{N}$-gain pada masing-masing kelompok. Data Ngain atau gain ternormalisai merupakan data yang diperoleh dengan membandingkan selisih skor postes dan pretes dengan selisih SMI dan pretes. Selain digunakan untuk melihat peningkatan kemampuan mahasiswa, data ini juga memberikan informasi mengenai pencapaian kemampuan mahasiswa. Dengan demikian, data N-gain memberikan informasi mengenai peningkatan kemampuan beserta peringkat mahasiswa dalam suatu kelompok.

b) Melakukan uji normalitas, homogenitas, uji perbedaan rerata dengan menggunakan uji ANOVA satu jalur.

HASIL PENELITIAN DAN PEMBAHASAN 
Hasil Penelitian

Seluruh perhitungan statistika dalam analisis ini menggunakan bantuan Microsoft Office Excel dan software SPSS, dengan tingkat signifikansi $5 \%$.
Berikut ini disajikan perbandingan rata-rata pretes, postes, dan $\mathrm{N}$-gain kemampuan pembuktian matematis mahasiswa pada tiga kelompok.

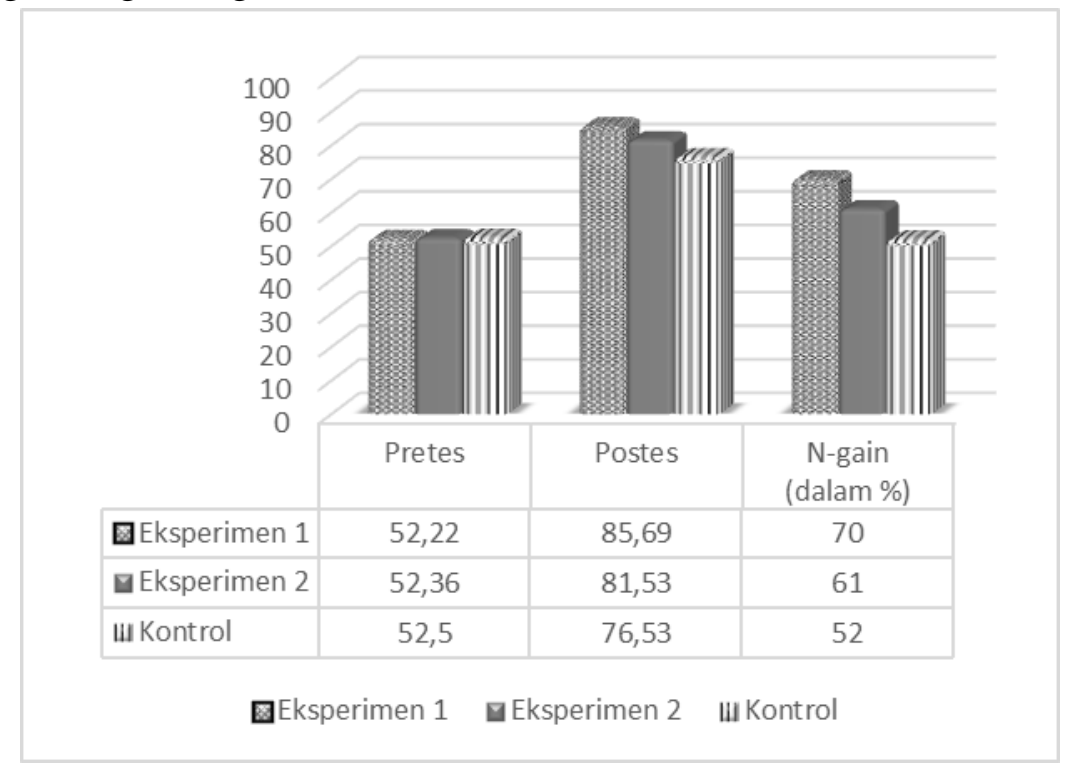

Gambar 3.

\section{Perbandingan Kemampuan Pembuktian Matematis}

Berdasarkan rata-rata pretes diketahui bahwa kemampuan awal pembuktian matematis mahasiswa tidak jauh berbeda. Hal ini dikarenakan peneliti menggunakan teknik sampling purposive dengan pencocokan subyek (matched subject), sehingga diperoleh kelompokkelompok yang ekuivalen (setara). Selanjutnya pada kelompok eksperimen 1 , peneliti mengaplikasikan teori CRS berbantuan bahan ajar mastery learning. Sedangkan pada kelompok eksperimen 2 peneliti mengaplikasikan teori CRS tanpa berbantuan bahan ajar masteri learning. Kemudian pada kelompok kontrol, peneliti mengaplikasikan teori konstrukstivisme. Ketiga perlakuan tersebut memiliki efek yang berbeda terhadap kemampuan pembuktian matematis mahasiswa. Hal tersebut dapat dilihat dari perbedaan rata-rata postes dan $\mathrm{N}$-gain pada ketiga kelompok. Namun untuk menguji apakah perbedaan tersebut signifikan secara statistik atau tidak, selanjutnya dilakukan pengujian hipotesis menggunakan uji ANOVA satu jalur. Berikut ini hasil uji ANOVA satu jalur menggunakan bantuan software SPSS. 
Tabel 2.

Uji Normalitas Peningkatan Kemampuan Pembuktian Matematis

\begin{tabular}{|l|r|r|r|r|r|r|}
\hline \multirow{2}{*}{} & \multicolumn{3}{|c|}{ Kolmogorow-Smirnore } & \multicolumn{3}{|c|}{ Shapiro-Wilk } \\
\cline { 2 - 7 } & Statistic & \multicolumn{1}{c|}{ df } & \multicolumn{1}{c|}{ Siq. } & Statistic & \multicolumn{1}{c|}{ df } & Siq. \\
\hline Kelompok Eksperimen 1 & .108 & 30 & $.200^{\circ}$ & .947 & 30 & .140 \\
Kelompok Eksperimen 2 & .118 & 30 & $.200^{\circ}$ & .955 & 30 & .233 \\
Kelompok Kontrol & .116 & 30 & $.200^{\circ}$ & .967 & 30 & .465 \\
\hline
\end{tabular}

a. Lilliefors Significance Correction

*. This is a lower bound of the true significance.

Tabel 3.

Uji Homogenitas Peningkatan Kemampuan Pembuktian Matematis Test of Homogeneity of Variances

\begin{tabular}{|c|c|c|c|}
\hline $\begin{array}{c}\text { Peningkatan_Kemamouan Pembuktian Matematis } \\
\text { Levene }\end{array}$ & $\mathrm{df1}$ & $\mathrm{df2}$ & Siq. \\
\hline 1.057 & 2 & 87 & .352 \\
\hline
\end{tabular}

Tabel 4.

Uji Anova Satu Jalur Peningkatan Kemampuan Pembuktian Matematis ANOVA

\begin{tabular}{|c|c|c|c|c|c|}
\hline & $\begin{array}{c}\text { Sum of } \\
\text { Squares }\end{array}$ & $\mathrm{df}$ & Mean Square & $\mathrm{F}$ & Siq. \\
\hline Between Groups & .488 & 2 & .244 & 13.484 & .000 \\
\hline Within Groups & 1.574 & 87 & .018 & & \\
\hline Total & 2.062 & 89 & & & \\
\hline
\end{tabular}

Tabel 5.

Uji Pos Hoc Menggunakan Uji Scheffe

Multiple Comparisons

Peningkatan Kemampuan Pembuktian Matematis

\begin{tabular}{|c|c|c|c|c|c|c|}
\hline \multirow[b]{2}{*}{ Grup } & \multirow[b]{2}{*}{$\begin{array}{l}\text { (J) } \\
\text { Grup }\end{array}$} & \multirow[b]{2}{*}{$\begin{array}{c}\text { Mean } \\
\text { Difference (1- } \\
J)\end{array}$} & \multirow[b]{2}{*}{ Std. Error } & \multirow[b]{2}{*}{ Sig. } & \multicolumn{2}{|c|}{$95 \%$ Confidence Interval } \\
\hline & & & & & Lower Bound & Upper Bound \\
\hline \multirow[t]{2}{*}{1} & 2 & $.08833^{\circ}$ & .03473 & .044 & .0018 & .1748 \\
\hline & 3 & $.18033^{\prime}$ & .03473 & .000 & .0938 & .2668 \\
\hline \multirow[t]{2}{*}{2} & 1 & $-.08833^{\circ}$ & .03473 & .044 & -.1748 & -.0018 \\
\hline & 3 & $.09200^{\circ}$ & .03473 & .034 & .0055 & .1785 \\
\hline \multirow[t]{2}{*}{3} & 1 & $-.18033^{\circ}$ & .03473 & .000 & -.2668 & -.0938 \\
\hline & 2 & $-.09200^{\circ}$ & .03473 & .034 & -.1785 & -.0055 \\
\hline
\end{tabular}

*. The mean difference is significant at the 0.05 level.

Pada Tabel 2 dan Tabel 3 dapat dilihat bahwa nilai sig untuk uji normalitas dan uji homogenitas lebih dari $\alpha=0,05$. Ini menunjukkan bahwa data $\mathrm{N}$-gain untuk masingmasing kelompok berdistribusi berdistribusi normal dan variansi ketiga kelompok homogen. Maka dari 
itu, asumsi untuk uji ANOVA satu jalur telah terpenuhi. Selanjutnya pada Tabel 3 diketahui bahwa nilai sig untuk uji ANOVA satu jalur lebih kecil dari $\alpha=0,05$. Hal ini menunjukkan bahwa terdapat perbedaaan rata-rata $\mathrm{N}$-gain pada ketiga kelompok. Untuk mengetahui kelompok mana yang berbeda maka dilakukan uji pos hoc menggunakan uji Scheffe. Hasil uji Scheffe yang disajikan pada Tabel 4 diperoleh nilai sig lebih kecil dari $\alpha=0,05$ yang menunjukkan bahwa kelompok eksperimen 1 berbeda secara signifikan dengan kelompok eksperimen 2 dan kelompok kontrol. Begitu juga pun kelompok eksperimen 2 berbeda secara signifikan dengan kelompok kontrol.

Perbedaan tersebut juga dapat terlihat dari rata-rata $\mathrm{N}$-gain kelompok eksperimen 1 yang tergolong tinggi yaitu sebesar 0,70 , sedangkan rata-rata $\mathrm{N}$-gain kelompok eksperimen 2 sebesar 0,61 dan kelompok kontrol sebesar 0,52 atau tergolong sedang. Dengan demikian, peningkatan kemampuan pembuktian matematis mahasiswa pada kelompok eksperimen 1 lebih baik dibandingkan dengan mahasiswa pada kelompok eksperimen 2 dan mahasiswa pada kelompok kontrol. Berdasarkan pengujian yang telah dilakukan, dapat disimpulkan bahwa pada taraf kepercayaan $95 \%$, terdapat perbedaan peningkatan kemampuan pembuktian matematis mahasiswa antara yang mendapatkan pembelajaran melalui aplikasi teori CRS berbantuan bahan ajar mastery learning, dengan mahasiswa yang mendapatkan pembelajaran melalui aplikasi teori CRS saja dan mahasiswa yang mendapatkan pembelajaran melalui aplikasi teori konstruktivisme.

Selanjutnya, berikut ini disajikan perbandingan rata-rata $\mathrm{N}$-gain untuk masing-masing indikator kemampuan pembuktian matematis mahasiswa pada tiga kelompok.

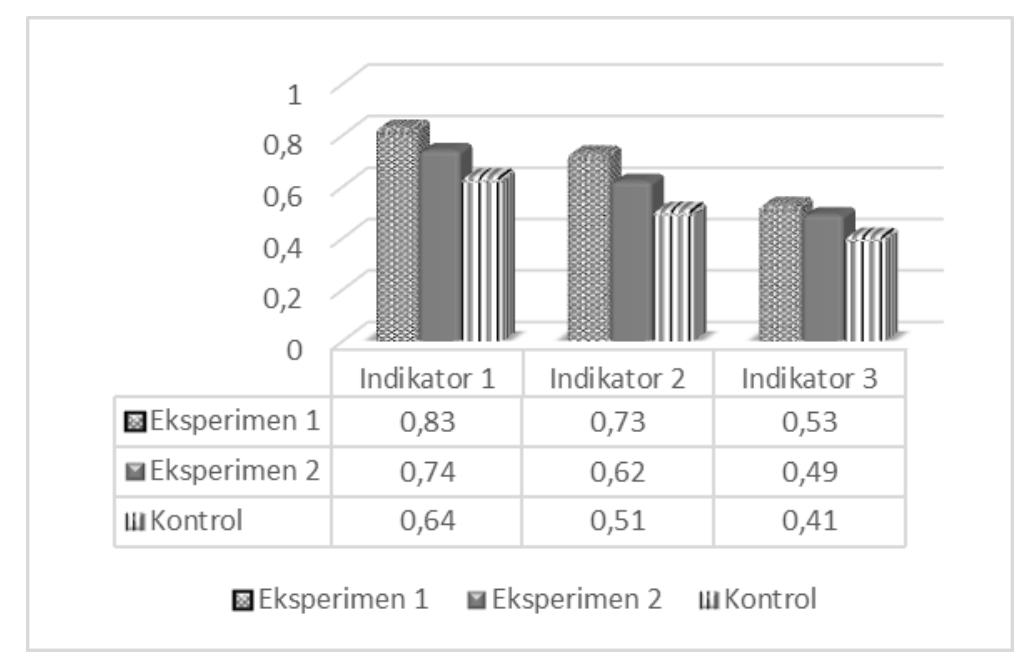

Gambar 3.

Perbandingan Indikator Kemampuan Pembuktian Matematis 
Berdasarkan Gambar 3 diketahui bahwa nilai rata-rata $\mathrm{N}$-gain untuk masing-masing indikator kemampuan pembuktian matematis pada kelompok eksperimen 1 lebih tinggi dibandingkan pada kelompok eksperimen 2 dan kelompok kontrol. Diketahui pula bahwa terdapat perbedaan peningkatan kemampuan pembuktian matematis mahasiswa pada kelompok eksperimen 1 berdasarkan pencapaian indikator kemampuan pembuktian matematis yang diukur. Namun untuk menguji apakah perbedaan tersebut signifikan secara statistik atau tidak, selanjutnya dilakukan pengujian hipotesis menggunakan uji ANOVA satu jalur. Berikut ini hasil uji ANOVA satu jalur menggunakan bantuan software SPSS.

Tabel 6.

Uji Normalitas Indikator Kemampuan Pembuktian Matematis

Tests of Normality

\begin{tabular}{|l|r|r|r|r|r|r|}
\hline & \multicolumn{3}{|c|}{ Kolmogorov-Smirnove } & \multicolumn{3}{c|}{ Shapiro-Wilk } \\
\cline { 2 - 7 } & Statistic & \multicolumn{1}{c|}{$\mathrm{df}$} & \multicolumn{1}{c|}{ Siq. } & \multicolumn{1}{c|}{ Statistic } & \multicolumn{1}{c|}{ df } & \multicolumn{1}{c|}{ Siq. } \\
\hline Indikator 1 & .365 & 30 & .000 & .724 & 30 & .000 \\
Indikator 2 & .207 & 30 & .002 & .889 & 30 & .005 \\
Indikator 3 & .310 & 30 & .000 & .824 & 30 & .000 \\
\hline
\end{tabular}

a. Lilliefors Significance Correction

Berdasarkan Tabel 6 dikeahui bahwa nilai sig untuk masing-masing indikator lebih kecil dari $\alpha=0,05$. Ini menunjukkan bahwa data $\mathrm{N}$-gain untuk masing-masing indikator tidak berdistribusi normal. Dengan demikian, asumsi untuk melakukan uji ANOVA satu jalur tidak terpenuhi, sehingga pengujian selanjutnya dilakukan secara non parametrik menggunakan uji Kruskal Wallis.

Tabel 7.

Uji Kruskal Wallis Indikator Kemampuan Pembuktian Matematis

Tests of Normality

\begin{tabular}{|l|r|r|r|r|r|r|}
\hline & \multicolumn{3}{|c|}{ Kolmogorov-Smirnove } & \multicolumn{3}{c|}{ Shapiro-Wilk } \\
\cline { 2 - 7 } & Statistic & \multicolumn{1}{c|}{$\mathrm{df}$} & \multicolumn{1}{c|}{ Siq. } & \multicolumn{1}{c|}{ Statistic } & \multicolumn{1}{c|}{ df } & \multicolumn{1}{c|}{ Siq. } \\
\hline Indikator1 & .365 & 30 & .000 & .724 & 30 & .000 \\
Indikator 2 & .207 & 30 & .002 & .889 & 30 & .005 \\
Indikator 3 & .310 & 30 & .000 & .824 & 30 & .000 \\
\hline
\end{tabular}

a. Lilliefors Significance Correction 
Tabel 8.

Uji Pos Hoc Menggunakan Uji Tuckey

Multiple Comparisons

Pencapaian Indikator Kemampuan Pembuktian Matematis

\begin{tabular}{|c|c|c|c|c|c|c|}
\hline \multirow[b]{2}{*}{ (1) } & \multirow[b]{2}{*}{$\begin{array}{l}\text { (J) } \\
\text { Grun }\end{array}$} & \multirow[b]{2}{*}{$\begin{array}{c}\text { Mean } \\
\text { Difference (l- } \\
\mathrm{J})\end{array}$} & \multirow[b]{2}{*}{ Std. Error } & \multirow[b]{2}{*}{ Sig. } & \multicolumn{2}{|c|}{$95 \%$ Confidence Interval } \\
\hline & & & & & Lower Bound & Upper Bound \\
\hline \multirow[t]{2}{*}{1} & 2 & .09233 & .06091 & .288 & -.0529 & .2376 \\
\hline & 3 & $.29200^{\circ}$ & .06091 & .000 & .1468 & .4372 \\
\hline \multirow[t]{2}{*}{2} & 1 & -.09233 & .06091 & .288 & -.2376 & .0529 \\
\hline & 3 & $.19967^{\prime}$ & .06091 & .004 & .0544 & .3449 \\
\hline \multirow[t]{2}{*}{3} & 1 & $-.29200^{\prime}$ & .06091 & .000 & -.4372 & -.1468 \\
\hline & 2 & $-.19967^{\prime}$ & .06091 & .004 & -.3449 & -.0544 \\
\hline
\end{tabular}

*. The mean difference is significant at the 0.05 level.

Berdasarkan uji Kruskal Wallis pada Tabel 6 diperoleh nilai sig sebesar 0,000 yang lebih kecil $\alpha=0,05$. Artinya terdapat perbedaaan pencapaian indikator kemampuan pembuktian matematis pada mahasiswa yang mendapatkan pembelajaran melalui aplikasi teori CRS berbantuan bahan ajar mastery learning. Selanjutnya berdasarkan uji Tukey diketahui bahwa pencapaian indikator 1 berbeda secara signifikan dengan pencapaian indikator 3 , dan pencaaian indikator 2 berbeda secara signifikan dengan pencapaian indikator 3. Akan tetapi pencapaian indikator 1 tidak berbeda secara signifikan dengan pencapaian indikator 2.

Perbedaan tersebut juga dapat terlihat dari rata-rata $\mathrm{N}$-gain indikator 1 dan indikator 2 yang tergolong tinggi yaitu secara berturut-turut sebesar 0,83 dan 0,74, sedangkan ratarata $\mathrm{N}$-gain indikator 3 sebesar 0,64 dan kelompok kontrol sebesar 0,52 atau tergolong sedang. Dengan demikian dapat dikatakan bahwa kemampuan mahasiswa yang mendapatkan pembelajaran melalui aplikasi teori CRS berbantuan bahan ajar mastery learning dalam membaca pembuktian matematis dan melakukan pembuktian matematis secara langsung, tak langsung, atau dengan induksi matematis tergolong tinggi. Sedangkan kemampuan mahasiswa dalam mengkritik pembuktian dengan menambah, mengurangi atau menyusun kembali suatu pembuktian matematis tergolong sedang. Berdasarkan pengujian yang telah dilakukan, dapat disimpulkan bahwa pada taraf kepercayaan $95 \%$, terdapat perbedaan peningkatan kemampuan pembuktian matematis mahasiswa yang mendapatkan pembelajaran melalui aplikasi teori CRS berbantuan bahan ajar mastery learning ditinjau berdasarkan pencapaian indikator kemampuan pembuktian matematis.

Dari uraian di atas, teori Conditioning-Reinforcement-

Scaffolding (CRS) memiliki pengaruh 
terhadap peningkatan kemampuan pembuktian matematis mahasiswa. Hal ini dikarenakan skema pembelajaran dengan teori CRS yang menggabungkan keunggulan teori conditioning dari Ivan P. Pavlov, teori reinforcement dari B.F.Skinner, dan teori scaffolding dari Lev S. Vygotsky. Penggabungan teori-teori tersebut didasarkan pada hasil penelitian Lestari dan Yudhanegara (2015). Disamping itu, konsep belajar tuntas (learning for mastery) yang digagas oleh Bloom (1968), yang dijadikan dasar untuk penyusunan bahan ajar mastery learning pada mata kuliah Teori Grup ini juga terbukti efektif dalam menciptakan lingkungan belajar yang memungkinkan mahasiswa untuk dapat menguasai kompetensi-kompetensi secara utuh dan tuntas (mastery learning) sesuai dengan kecepatan belajarnya.

\section{KESIMPULAN DAN SARAN Kesimpulan}

1. Pada taraf kepercayaan 95\%, terdapat perbedaan peningkatan kemampuan pembuktian matematis mahasiswa antara yang mendapatkan pembelajaran melalui aplikasi teori CRS berbantuan bahan ajar mastery learning, dengan mahasiswa yang mendapatkan pembelajaran melalui aplikasi teori CRS saja dan mahasiswa yang mendapatkan pembelajaran melalui aplikasi teori konstruktivisme.

2. Pada taraf kepercayaan 95\%, terdapat perbedaan peningkatan kemampuan pembuktian matematis mahasiswa yang mendapatkan pembelajaran melalui aplikasi teori CRS berbantuan bahan ajar mastery learning ditinjau berdasarkan pencapaian indikator kemampuan pembuktian matematis.

\section{Saran}

Bagi peneliti selanjutnya, disarankan untuk melakukan beberapa perbaikan dalam mengimplementasikan teori CRS pada mata kuliah Teori Grup agar peningkatan kemampuan pembuktian matematis dapat mencapai peningkatan kemampuan pembuktian matematis mahasiswa pada mata kuliah Teori Grup. Selain itu teori CRS agar diimplementasikan pada model/strategi/metode/teknik

pembelajaran dalam perkuliahan khususnya bagi mahasiswa non reguler.

\section{DAFTAR RUJUKAN}

Bloom. (1968). "Learning for Mastery". Journal Center for The Study of Evaluation of Instructional Programs, 1 (2), halaman 12.

Findel, B. R. (2001). Learning and Understanding in Abstract Algebra. Disertasi New Hampshire: tidak diterbitkan.

Lestari, K. E. (2015). "Analisis Kemampuan Pembuktian Matematis Mahasiswa Menggunakan Pendekatan Induktif-Deduktif Pada Mata Kuliah Analisis Real Lanjut”. Jurnal Mendidik: Kajian Pendidikan dan Pengajaran Universitas Mathla'ul Anwar Banten, 1 (2), halaman 128135.

Lestari, K.E., dan Yudhanegara, M.R. (2015). Penelitian Pendidikan 
Matematika. Bandung: CV Refika Aditama.

Yudhanegara, M. R., dan Lestari, K. E. (2017). "How to Develop Students' Expereince on Mthematical Proof in Group Theory Course by Conditioning-Reinforcement-
Scaffolding (CRS)". Proceedings: 5th South East Asia Development Research (SEA-DR) International Conference, Advances in Science, Education adn Humanities Research, volume 100, halaman 186-189. 